\title{
Effectiveness of Structured Teaching Programme on Knowledge Regarding Oral Health Hazards among Tobacco Users in Selected Village at Villupuram
}

\author{
M.Porselvi ${ }^{1}$, Karthi.R ${ }^{2}$, G.Ranjith Kumar ${ }^{3}$, P.Reshma ${ }^{4}$, B.Rasiga ${ }^{5}$, R.Rajashree ${ }^{6}$, \\ S.Salethmary ${ }^{7}$, A.Santhiya ${ }^{8}$, V.Sandhiya ${ }^{9}$ \\ ${ }^{1}$ Professor cum Principal, E.S. College of Nursing, Villupuram, Tamilnadu \\ ${ }^{2}$ Professor cum Vice Principal, E.S. College of Nursing, Villupuram, Tamilnadu \\ ${ }^{3-9}$ B.Sc(N) E.S. College of Nursing, Villupuram, Tamilnadu \\ Corresponding Author: M.Porselvi
}

\section{ABSTRACT}

Aim: The study aims to create awareness among Tobacco users on knowledge regarding Oral Health Hazards.

Objectives:

i) To assess the pre and post test level of knowledge of oral health hazards among tobacco users.

ii) To assess the effectiveness of structured teaching programme on knowledge of oral health hazards among tobacco users.

iii) To find the association between post test level of knowledge regarding oral health hazards among tobacco users with their socio demographic variables.

Methods \& Materials: A quantitative research approach-Pre-experimental research design with one group pre test and post test design was adopted. 50 samples were selected for the study by using non probability purposive sampling technique.

Results: The study findings shows that in pre test level of knowledge among 50 samples $42(84 \%)$ had inadequate knowledge and $8(16 \%)$ had moderate adequate knowledge. In post test level of knowledge among 50 samples 33(66\%) had moderate adequate knowledge and 17(34\%) had had excellent knowledge. The pre test mean was 5.74 with the standard deviation of 10.29 and the post test mean was 14.6 with the standard deviation of 9.91 the mean difference of pre and post is 8.86; standard error is 1.401 ' $t$ ' value is 34.775 significant at $p<0.05$ it indicates that the knowledge level of tobacco users improved after structured teaching programme. The finding of the study shows that there is significant association between level of knowledge with occupation $\mathrm{p}<0.05$.

Conclusion: The study finding shows that, the post test level of knowledge is better than the pre-test knowledge. Hence it can be concluded that, structured teaching programme on oral health hazards was effective in improving the knowledge level among tobacco users.

Keys words: Tobacco users, Oral Health Hazards

\section{INTRODUCTION}

According to WHO, health is state of complete physical, mental, social and spiritual well being and merely absence of disease or infirmity. Oral health as a state of being free from chronic mouth and facial pain, oral and throat cancer, oral infection and some periodontal(gum) disease, tooth decay, tooth loss and other disease and disorders that limit an individual capacity in biting, cheering, smiling, speaking and psycho social activities.

Tobacco consumption is a global problem; it is the single most preventable cause for adult death and disease in the world day. It is estimated that one in three people use tobacco products, with over 1 million people use tobacco and its products worldwide .nearly four million of the world population would have been saved from the clutches of death due to tobacco addiction. 
nicotine is a highly addictive substance and adult people experimentation can easily lead to a life time of tobacco dependence.

Second hand smoke is the combination of smoke from the burning end of cigarette and the smoke contains more than 7000 chemicals. 100 are toxic and about 70 can cause cancer .since the 1964 surgeon general's report, 2.5 million adults who were non smokers died because they breathed second hand smoke.(KH Awan 2011).

The nicotine in tobacco reduces saliva flow and some smokers can get dry mouth symptoms. The saliva of smokers is sometimes thicker which means it does not protect the teeth as well as mouth. Smoking can also cause or worsen gum disease also called periodontal disease and increase the risk of mouth and lip cancer, oral cancer.

Some of the long term effects of smoking that may be experienced include loss of taste, yellow teeth, tooth decay, cancer of the nose, lip, tongue and mouth. Increased risk of leukoplakia, white patches inside the mouth, a leading cause of tooth loss, delayed healing process following tooth extraction, periodontal treatment or oral surgery.

The damaging and harmful effects of tobacco usage on oral health are now well recognized, in particular higher prevalence and severity of periodontal diseases among smokers and the association of tobacco use with candidosis and with oral malignancies. Several recent documents have reviewed the scientific evidence relating to the oral disease burden attributable to tobacco use and have highlighted the role and the need for the dental profession to get involved with tobacco intervention.

About $90 \%$ of people with cancer of the mouth, lips, tongue and throat use tobacco and risk of developing these cancers increases with the amount smoked or chewed and the duration of the habit. smokers are 6 times more likely than not smokers to develop these cancers

About $37 \%$ of patients who persist in smoking after apparent care of their cancer will develop second cancers of the mouth, lips, tongue and throat compared with only $6 \%$ of those who stop smoking.

\section{Statement of the Problem}

A study to assess the effectiveness of structured teaching programme on knowledge regarding oral health hazards among tobacco users in selected village Villupuram.

\section{Objectives}

1. To assess the pre and post test level of knowledge of oral health hazards among tobacco users.

2. To assess the effectiveness of structured teaching programme on knowledge of oral health hazards among tobacco users.

3. To find the association between the post test level of knowledge of oral health hazards among tobacco users with their socio demographic variables

\section{NULL HYPOTHESIS}

$\mathrm{HN}_{1}$ : There is no significant difference between the pre and post level of knowledge on oral health hazards among tobacco users. $\mathrm{HH}_{2}$ : There is no significant association between level of knowledge of oral health hazards among tobacco users with their selected socio demographic variables.

\section{METHODS}

A quantitative research approachPre-experimental research design with one group pre test and post test design was adopted. 50 samples were selected for the study by using non probability purposive sampling technique. 
M.Porselvi et.al. Effectiveness of structured teaching programme on knowledge regarding oral health hazards among tobacco users in selected village at Villupuram

\subsection{Assessment of pre and post test level of knowledge regarding oral health hazards among tobacco users.}

Table 4.2.1 frequency and percentage distribution of pre test level of knowledge regarding oral health hazards among tobacco users.

\begin{tabular}{|l|c|c|c|c|}
\hline \multirow{2}{*}{ Level of knowledge } & \multicolumn{2}{|c|}{ Pre Test } & \multicolumn{2}{c|}{ Post Test } \\
\cline { 2 - 5 } & Frequency (N) & Percentage (N\%) & Frequency (N) & Percentage (N\%) \\
\hline Inadequate & 42 & $84 \%$ & 0 & 0 \\
\hline Moderate & 8 & $16 \%$ & 33 & $66 \%$ \\
\hline Adequate & 0 & 0 & 17 & $34 \%$ \\
\hline
\end{tabular}

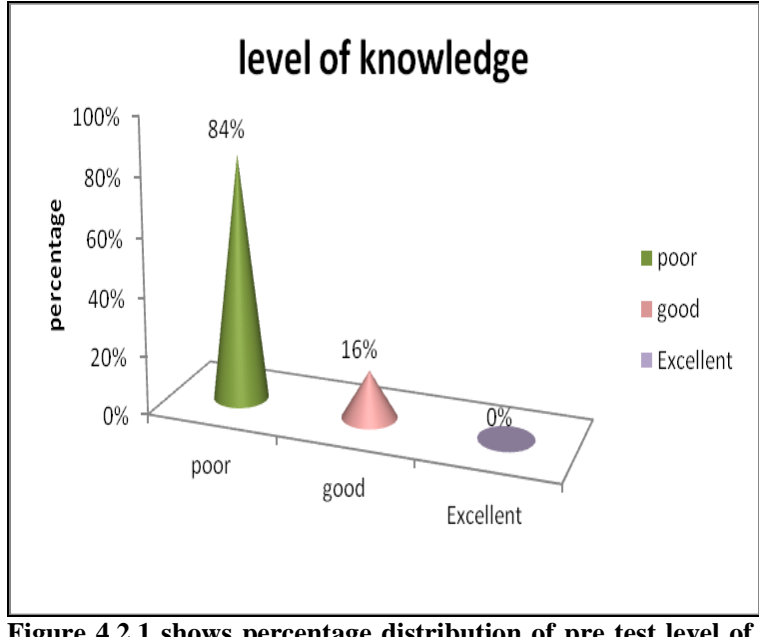

Figure 4.2.1 shows percentage distribution of pre test level of knowledge among tobacco users

Table 4.2.1 Shows that in pre test level of knowledge among 50 samples $42(84 \%)$ had poor knowledge and $8(16 \%)$ good knowledge and in post test level of knowledge among 50 samples 33(66\%) had good knowledge and 17(34\%) had excellent knowledge.

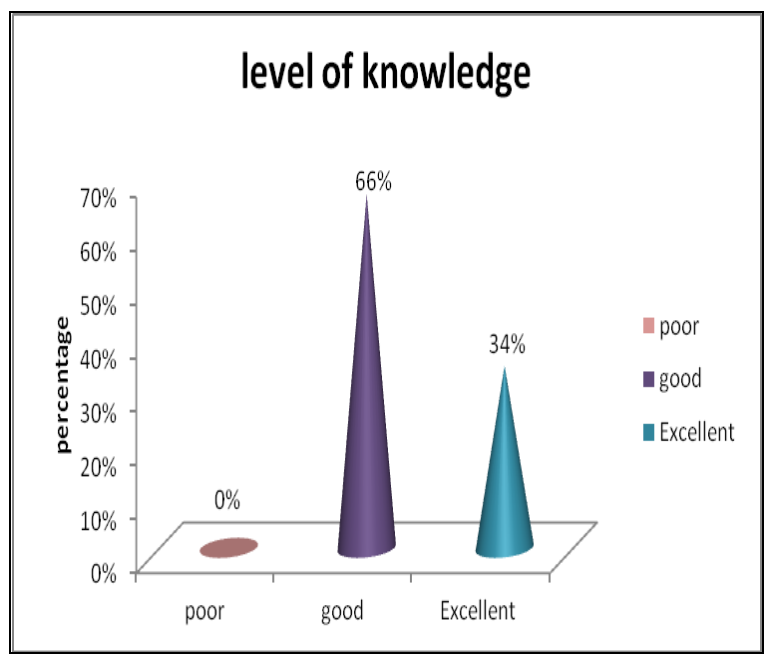

Figure 4.2.2 shows percentage distribution of post test level of knowledge among tobacco users.

\section{Effectiveness of structured teaching programme on knowledge regarding oral health} hazards among tobacco users.

Table4.3 Effectiveness of structured teaching programme on knowledge regarding oral health hazards among tobacco users.

\begin{tabular}{|c|c|c|c|c|c|c|}
\hline \multicolumn{2}{|c|}{ Pre test } & \multicolumn{2}{c|}{ Post test } & $\begin{array}{c}\text { Mean } \\
\text { difference }\end{array}$ & $\begin{array}{c}\text { Standard } \\
\text { error }\end{array}$ & T value \\
\cline { 1 - 3 } mean & $\begin{array}{c}\text { Standard } \\
\text { deviation }\end{array}$ & mean & $\begin{array}{c}\text { Standard } \\
\text { deviation }\end{array}$ & & & \\
\hline 5.74 & 10.29 & 14.6 & 9.91 & 8.86 & 1.401 & $34.76^{*}$ \\
\hline \multicolumn{7}{|c|}{ Significant at $\mathrm{P}<0.5$} \\
\hline
\end{tabular}

Table 4.3 reveals that pre test means was 5.74 with the standard deviation of 10.29 and the post test mean was 14.6 with the standard deviation of 9.91. The mean difference of pre and post test is 8.86; standard error is 1.401 . The " $T$ " value is 34.776 is significant at $\mathrm{p}<0.05$ it indicates that the knowledge level of tobacco users are improved after video assisted teaching programme.
4.4. Association between post test level of knowledge with their selected socio demographic variables.

Table shows that there is significant association between level of knowledge with occupation at $p<0.05$ and there is no significant association between level of knowledge with age in years, gender, religion, education, marital status, family income, type of tobacco consumption, year of tobacco consumption and frequency of tobacco consumption. 
M.Porselvi et.al. Effectiveness of structured teaching programme on knowledge regarding oral health hazards among tobacco users in selected village at Villupuram

\begin{tabular}{|c|c|c|c|c|c|c|}
\hline \multirow[b]{2}{*}{ S.no } & \multirow[b]{2}{*}{ Variables } & \multicolumn{3}{|c|}{ Level of knowledge } & \multirow[b]{2}{*}{ Chi-square test } & \multirow[b]{2}{*}{ P-Value } \\
\hline & & Poor & Good & $\begin{array}{c}\text { Excel- } \\
\text { Lent }\end{array}$ & & \\
\hline \multirow[t]{4}{*}{1} & Age in years & & & & & \\
\hline & a) $20-30 \mathrm{yrs}$ & 0 & 4 & 4 & \multirow{3}{*}{$\begin{array}{c}1.43 \\
D F=4\end{array}$} & \multirow{3}{*}{$\begin{array}{c}0.88739 \\
{[\mathrm{NS}]}\end{array}$} \\
\hline & b) $31-40$ yrs & 0 & 10 & 5 & & \\
\hline & c) $41-50 \mathrm{yrs}$ & 0 & 19 & 8 & & \\
\hline \multirow[t]{3}{*}{2} & Gender & & & & & \\
\hline & a)Male & 0 & 33 & 17 & \multirow{2}{*}{$\begin{array}{c}0 \\
\mathrm{DF}=2\end{array}$} & \multirow{2}{*}{$\begin{array}{c}1 \\
{[\mathrm{NS}]}\end{array}$} \\
\hline & b)female & 0 & 0 & 0 & & \\
\hline \multirow[t]{4}{*}{3} & Religion & & & & & \\
\hline & a)Hindu & 0 & 33 & 17 & \multirow{3}{*}{$\begin{array}{c}0 \\
\mathrm{DF}=4\end{array}$} & \multirow{3}{*}{$\begin{array}{c}1 \\
{[\mathrm{NS}]}\end{array}$} \\
\hline & b)Muslim & 0 & 0 & 0 & & \\
\hline & c)Christian & 0 & 0 & 0 & & \\
\hline \multirow[t]{5}{*}{4} & Education & & & & & \\
\hline & a)Illiterate & 0 & 11 & 3 & \multirow{4}{*}{$\begin{array}{l}8.855 \\
\mathrm{DF}=6\end{array}$} & \multirow{4}{*}{$\begin{array}{c}0.18189 \\
{[\mathrm{NS}]}\end{array}$} \\
\hline & b)Primary & 0 & 0 & 0 & & \\
\hline & c)Secondary & 0 & 22 & 10 & & \\
\hline & d)Graduate \& above & 0 & 0 & 4 & & \\
\hline \multirow[t]{5}{*}{5} & Marital Status & & & & & \\
\hline & a)Married & 0 & 33 & 13 & \multirow{4}{*}{$\begin{array}{l}0.437 \\
\mathrm{DF}=6\end{array}$} & \multirow{4}{*}{$\begin{array}{c}0.20723 \\
{[\mathrm{NS}]}\end{array}$} \\
\hline & b)Unmarried & 0 & 0 & 4 & & \\
\hline & c)Divorce & 0 & 0 & 0 & & \\
\hline & d)Widow & 0 & 0 & 0 & & \\
\hline \multirow[t]{4}{*}{6} & Occupation & & & & & \\
\hline & a)Unemployed & 0 & 5 & 4 & \multirow{3}{*}{$\begin{array}{l}0.531 \\
D F=4\end{array}$} & \multirow{3}{*}{$\begin{array}{c}0.01 \\
{[S]}\end{array}$} \\
\hline & b)Farmer & 0 & 28 & 13 & & \\
\hline & c)Retired & 0 & 0 & 0 & & \\
\hline \multirow[t]{5}{*}{7} & Family income & & & & & \\
\hline & a)Rs.5000-10000 & 0 & 26 & 11 & & \\
\hline & b)Rs. $10000-15000$ & 0 & 7 & 6 & 1.154 & 0.979096 \\
\hline & c)Rs. $15000-20000$ & 0 & 0 & 0 & $\mathrm{DF}=6$ & [NS] \\
\hline & d)>Rs. 20000 & 0 & 0 & 0 & & \\
\hline 8 & Type of Tobacco Consumption & & & & & \\
\hline & a)Beedi(or)Cigarette & 0 & 20 & 9 & 0.268 & 0.991785 \\
\hline & b)Chewing & 0 & 13 & 8 & $\mathrm{DF}=4$ & {$[\mathrm{NS}]$} \\
\hline & c)Gutkha & 0 & 0 & 0 & & \\
\hline 9 & Year of Tobacco Consumption & & & & & \\
\hline & a)1-5 yrs & 0 & 23 & 10 & 0.589 & 0.744904 \\
\hline & b) $>5$ yrs & 0 & 10 & 7 & $\mathrm{DF}=2$ & [NS] \\
\hline 10 & Frequency of Tobacco Consumption & & & & & \\
\hline & a)Single use & 0 & 3 & 5 & & \\
\hline & b)2-5 Times & 0 & 13 & 8 & 5.838 & 0.44158 \\
\hline & c)5-10 Times & 0 & 8 & 3 & $\mathrm{DF}=6$ & {$[\mathrm{NS}]$} \\
\hline & d)>10 Times & 0 & 9 & 1 & & \\
\hline
\end{tabular}

Significant at $\mathrm{P}<0.5$

\section{Association between Post-Test Scores of Knowledge Regarding Breast Self Examination with their Selected socio Demographic Variables}

Table.4.5: Association between post test scores of knowledge regarding breast self examination with selected demographic variables.

\begin{tabular}{|c|c|c|c|c|c|c|}
\hline $\begin{array}{c}\text { Demographic } \\
\text { variables }\end{array}$ & $\begin{array}{l}\text { Inadequate } \\
\text { knowledge }\end{array}$ & $\begin{array}{l}\text { Moderate } \\
\text { knowledge }\end{array}$ & $\begin{array}{l}\text { Adequate } \\
\text { knowledge }\end{array}$ & df & $\mathbf{X}^{2}$ & Table value \\
\hline \multicolumn{7}{|l|}{ Age in years. } \\
\hline a)20-35 years & 0 & 3 & 2 & \multirow{3}{*}{4} & \multirow{3}{*}{3.564} & \multirow{3}{*}{$\begin{array}{l}0.468214 \\
\text { NS }\end{array}$} \\
\hline b) $35-45$ years & 0 & 3 & 14 & & & \\
\hline c)45 years above & 0 & 2 & 6 & & & \\
\hline \multicolumn{7}{|l|}{ Religion. } \\
\hline a) Hindu & 0 & 8 & 22 & \multirow{3}{*}{6} & \multirow{3}{*}{0} & \multirow{3}{*}{$\begin{array}{c}1 \\
\text { NS }\end{array}$} \\
\hline b) Muslim & 0 & 0 & 0 & & & \\
\hline c) Christian & 0 & 0 & 0 & & & \\
\hline \multicolumn{7}{|l|}{ Education status } \\
\hline a) Illiterate & 0 & 2 & 2 & \multirow{3}{*}{4} & \multirow{3}{*}{4.174} & \multirow{3}{*}{$\begin{array}{c}0.382969 \\
\text { NS }\end{array}$} \\
\hline b) Primary education & 0 & 3 & 17 & & & \\
\hline c) Degree and above & 0 & 3 & 3 & & & \\
\hline \multicolumn{7}{|l|}{ Marital status. } \\
\hline a) Unmarried & 0 & 5 & 5 & \multirow{4}{*}{6} & \multirow{4}{*}{4.189} & \multirow{4}{*}{$\begin{array}{l}0.651117 \\
\text { NS }\end{array}$} \\
\hline b) Married & 0 & 3 & 17 & & & \\
\hline c) Widow & 0 & 0 & 0 & & & \\
\hline d) Separated & 0 & 0 & 0 & & & \\
\hline
\end{tabular}


M.Porselvi et.al. Effectiveness of structured teaching programme on knowledge regarding oral health hazards among tobacco users in selected village at Villupuram

\begin{tabular}{|c|c|c|c|c|c|c|}
\hline \multicolumn{7}{|c|}{ Table 4.5: continued.... } \\
\hline Occupation of the mot & & & & & & \\
\hline a) House wife & 0 & 2 & 8 & \multirow{4}{*}{6} & \multirow{4}{*}{0.337} & \multirow{4}{*}{$\begin{array}{c}0.999297 \\
\quad \text { NS }\end{array}$} \\
\hline b) Salaried & 0 & 0 & 0 & & & \\
\hline c) Business & 0 & 0 & 0 & & & \\
\hline d) Daily wages & 0 & 6 & 14 & & & \\
\hline \multicolumn{7}{|c|}{ Total number of pregnancy. } \\
\hline a) Nil & 0 & 1 & 2 & \multirow{4}{*}{6} & \multirow{4}{*}{4.914} & \multirow{4}{*}{$\begin{array}{c}0.55489 \\
\text { NS }\end{array}$} \\
\hline b) $1-2$ & 0 & 1 & 14 & & & \\
\hline c) 3-4 & 0 & 5 & 5 & & & \\
\hline d) $5 \&$ above & 0 & 1 & 1 & & & \\
\hline \multicolumn{7}{|c|}{ Income of the family per month. } \\
\hline a) Rs. $<5000$ & 0 & 1 & 2 & \multirow{4}{*}{6} & \multirow{4}{*}{6.337} & \multirow{4}{*}{$\begin{array}{c}0.386517 \\
\text { NS }\end{array}$} \\
\hline b)Rs. $5000-10000$ & 0 & 1 & 14 & & & \\
\hline c)Rs. $10000-15000$ & 0 & 5 & 5 & & & \\
\hline d)Rs. 15000 or above & 0 & 1 & 1 & & & \\
\hline \multicolumn{7}{|l|}{ Diet pattern. } \\
\hline a) Vegetarian & 0 & 1 & 1 & \multirow[t]{2}{*}{2} & \multirow[t]{2}{*}{0.596} & \multirow{2}{*}{$\begin{array}{c}0.742301 \\
\text { NS }\end{array}$} \\
\hline b) Non vegetarian & 0 & 7 & 21 & & & \\
\hline \multicolumn{7}{|c|}{ Is there any history of breast cancer in family. } \\
\hline a) Yes & 0 & 2 & 3 & \multirow[t]{2}{*}{2} & \multirow[t]{2}{*}{0.543} & \multirow{2}{*}{$\begin{array}{c}0.762235 \\
\text { NS } \\
\end{array}$} \\
\hline b) No & 0 & 6 & 19 & & & \\
\hline \multicolumn{7}{|c|}{ Source of information regarding breast cancer. } \\
\hline a) Teacher & 0 & 0 & 0 & \multirow{4}{*}{6} & \multirow{4}{*}{0.997} & \multirow{4}{*}{$\begin{array}{c}0.985726 \\
\text { NS }\end{array}$} \\
\hline b) Mass media & 0 & 2 & 8 & & & \\
\hline c)Health care providers & 0 & 5 & 13 & & & \\
\hline d) Other & 0 & 1 & 1 & & & \\
\hline
\end{tabular}

From the above table it is evident that there is no significant association exist between post test score of knowledge regarding Breast self examination with selected demographic variables.

\section{DISCUSSION}

\section{Frequency and percentage distribution of Tobacco users,}

Among 50 samples, according to age of tobacco users $8(16 \%)$ belongs to $20-30$ years, $15(30 \%)$ belongs to $31-40$ years, $27(54 \%)$ belongs to 41-50years.According to gender $50(100 \%)$ belongs to male. According to religion 50(100\%) belongs to Hindu. According to education 14(28\%) belongs to primary education, 32(64\%) belongs to secondary education, $4(8 \%)$ belongs to graduate and above. According to marital status $46(92 \%)$ belongs to married and $4(8 \%)$ belongs to unmarried. According to occupation $9(18 \%)$ belongs to unemployed and 41(82\%) belongs to farmer. According to family income $37(54 \%)$ belongs to Rs.5000-10,000 and 13(26\%) belongs to Rs.10,000-15,000. According to type of tobacco consumption $29(58 \%)$ belongs to beedi or cigarette and $21(42 \%)$ belongs to chewing. According to year of tobacco consumption $33(66 \%)$ belongs to $1-5$ years and $17(34 \%)$ belongs to >5years .According to frequency of tobacco consumption 21(42\%) belongs to 2-5 times, $11(22 \%)$ belongs to 5-10 time and $10(20 \%)$ belongs to $>10$ time.

First objective of study is to assess the pre and post test level of knowledge on oral health hazards among tobacco users.

The findings shows that in pre test level of knowledge among 50 samples $42(84 \%)$ had poor knowledge and $8(16 \%)$ had good knowledge. In post test level of knowledge among 50 samples 33(66\%) had good knowledge and 17(34\%) had excellent knowledge.

\section{Second objectives of study are to assess the effectiveness of structured teaching programme on knowledge regarding oral health hazards of tobacco users.}

The finding $\mathrm{s}$ shows that pre test mean was 5.74 with the standard deviation of 10.29 and the post test mean was 14.6 with the standard deviation of 9.91.The mean difference of pre and post test is 8.86 standard error is 1.401 .

The " $T$ " value is 34.76 is significant at $\mathrm{p}<0.05$ it indicates that the knowledge level of tobacco users are improved after structured teaching programme. 
The third objective of the study is to find the association between knowledge regarding oral health hazards among tobacco users with socio demographic variables.

The findings shows that there is significant association between level of knowledge with occupation at $\mathrm{p}<0.05$.

\section{CONCLUSION}

The findings of the study shows that in level of knowledge among pre test mean was 5.74 with SD of 10.29 and the post test mean was 14.6 with SD of 9.91 the knowledge $\mathrm{T}$ value is 34.776 significant at $\mathrm{p}<0.05$ the study concluded the structured teaching programme was effective and improve knowledge regarding oral health hazards among tobacco users.

\section{Acknowledgement: None}

\section{Conflict of Interest: None}

\section{Source of Funding: None}

\section{REFERENCES}

\section{Book Reference}

1. CM Marya (2015) the text book of public health dentistry, $4^{\text {th }}$ edition published by jaypee brothers medical publication.

2. Tanushree keswani (2018) the text book of tobacco and oral health, $5^{\text {th }}$ edition CBS publishers (p) ltd.

3. Amit kumar (2017) the text book of smokeless tobacco and oral health, $2^{\text {nd }}$ edition published by LAMBERT academic publishers.

4. Greenspan (2019) the text book of tobacco and oral cancer, $1^{\text {st }}$ edition published by Springer international publishers.

5. Suresh K Sharma (2018) the text book of nursing research and statistics, $3^{\text {rd }}$ edition published by Elsevier publishers.

\section{Journal Reference}

1. Warnakulasuriya $\mathrm{S}$, Dietrich $\mathrm{T}$, Bornstein $\mathrm{MM}$, Walter C, et al. Oral health risks of tobacco use and effects of cessation. Int Dent J.(2018);60:7-30

2. Gupta PC tobacco- specific nitrosamines in smokeless tobacco products marked in India. Int J cancer.2005;116:16-9.

3. Axell T, Anderson G, Larsson A. Oral mucosal findings associated with chewing tobacco in Sweden-A clinical and histological study. J Dent assoc S Afr.2010; 47:194-6.

4. Javed F, Chotai M, Mehmood A, Almas K. Oral mucosal disorders associated with habitual gutka usage: a review: Oral Surg Oral Med Oral Pathol Oral Radiol Endod. 2010 Jun;109(6):857-64. doi: 10.1016/ j.tripleo.2009.12.038.

5. Skjoldebrand J, gahnberg L: Tobacco preventive measures by dental care staff: An attempt to reduce the use of tobacco among adolescents. Swend Dent J 2006;49-54.

6. Fiore MC, Bailey WC, cohen SJ: treating tobacco use and dependence. Rockvile, US Department of health \& Human services, public health service, 2000.

7. Opanuga $\mathrm{OA}$ et al. "smokeless tobacco knowledge, attitude and use among adults. South-west, Nigeria research gate, 2020;76: 34-53.

8. Mohammed ashief nazir et.al global prevalence of tobacco use in adolescent and its adverse oral health consequences, open acess Macedonian journal of medical sciences: 2019;46:81-7.

9. Keerthana R, Geetha RV "prevalence of caries in smokers and non- smokers, jpr solutions info: 2018;15:22-45.

10. Arvind muthukrishnan, saman warnakulasuriya, oral health consequences of smokeless tobacco use: Indian journal of medical research; 2018:35;301-310.

How to cite this article: M.Porselvi, Karthi.R, G.Ranjith Kumar et.al. Effectiveness of structured teaching programme on knowledge regarding oral health hazards among tobacco users in selected village at Villupuram. Galore International Journal of Applied Sciences \& Humanities. 2021; 5(3): 20-25. DOI: https:// doi.org/10.52403/gijash.20210703 